\title{
The Impact of Chinese Economic Increase on Economy of Northeast Asia
}

\author{
CHEN Zhi-jun, LUO Xiao-yan \\ (School of Economics \& Management, Shijiazhuang Railway Institute, Shijiazhuang 050043, China)
}

\begin{abstract}
Chinese economic total quantity has leaped to the sixth in the world because of the fast development for nearly 30 years, and become the world economics powerful nation gradually. The Chinese economic growth has influenced tremendously on the world economic development. Being Chinese close neighbor, how has the Northeast Asia be influenced? This paper will elaborate from the following three aspects: Chinese economic increase made China become important strength to promote the process of regional cooperation; Chinese economic increase made the pattern of Northeast Asian cooperation in economy and trade changed; competition and difference that Chinese economic increase brought to Northeast Asia. The increase of Chinese economic has positive influence on the economy of Northeast Asia, and is one of the powers causing the Northeast Asian economy to grow. At the same time, this kind of influence is mutual. In particular the economic cooperation with Japan is the key to establish the integration of the Northeast Asian economy.
\end{abstract}

Key words: economy; impact; Northeast Asia

\section{Introduction}

Northeast Asia is an important component of Asia. Under the fierce impact of globalization and the regional cooperation, Northeast Asia is going through the unprecedented test. In Northeast Asian area, territory is vast, resources are abundant, the market is enormous, industrial structure and goods structure are with strong complementary, the economic links each other and have been already quite close, the integration and dependence rely each other strengthen constantly. Various countries can get interests from the regional cooperation. China should take the historical important task to promote the regional cooperation bravely.

\section{Chinese Economic Increase Makes China Become Important Strength to Promote the Process of Regional Cooperation}

Because Chinese economy increases continuously and the economic strength is stronger and stronger, China already possessed the strength to promote the process of regional cooperation, and gave full play to this kind of strength actively, make the regional cooperation develop faster. Because of the questions left over from history and different thinking of development, China, Japan and S. Korea can not form the economic intergrowth relation in a short time. Therefore, establishing the Northeast Asian free trade area need some time. China developed actively regional cooperation with ASEAN and achieved success, which affected the economy of Japan and S. Korea in ASEAN, and made Japan and S. Korea develop actively regional cooperation with ASEAN. Under the

CHEN Zhi-jun(1971- ), Master, lecturer of School of Economics \& Management, Shijiazhuang Railway Institute; research field: international trade.

LUO Xiao-yan(1975- ), lecturer of School of Economics \& Management, Shijiazhuang Railway Institute; research field: accounting. 
leadership of China, ASEAN-China free trade district, ASEAN-Japan free trade district and ASEAN-S. Korea free trade district are coming being. Though the free trade area like ASEAN among China, Japan and S. Korea can't be formed in a short time, three countries still sought actively the possibility of developing regional economy. On October 7, 2003, the leaders of China, Japan and S. Korea held the meeting in Bali of Indonesia, signed and published "The Joint Declaration to Advance Three Sides Cooperation among China and Japan and S. Korea" (hereafter abbreviate "joint declaration"). In the "joint declaration", the leaders of three nations agreed to advance cooperation in 14 fields such as economy and trade, culture, personnel exchange, politics and security, etc. and established the tripartite committee lead by foreign ministers of three countries to research, plan, coordinate and supervise the concrete cooperation. In June of 2004, the first session of the tripartite committee held in Qingdao of China. The foreign ministers of three countries agreed unanimously to refer "Cooperative Action Strategy of China, Japan and S. Korea” to the tripartite leaders meeting held in Laos in November. They discussed extensively and deeply of the requisite measures to promote trade and investment, such as strengthen the intergovernmental coordination of policies and measures, promote understand and cooperation through the tripartite committee, the council of economic and trade ministers of the three countries, the economic department chief consultation, China-Japan economic partner consultation, Japan-Korea on the senior level economic consultation, China-Korea unite economic commission, etc.. A research group was formed to study jointly on the free trade agreement among the three nations. The research group refers "The Report and Policy Recommendations of Strengthening the Cooperation of Three Sides" to the leaders meeting of the three nations in 2003, assessing mainly the possible economic influence to set up the free trade agreement of the three nations, and thought the agreement would bring the substantive macro-economy income to the three nations. The report of the union research group included the following views mainly: first, promoting the direct investment among the three countries is helpful for them to realize the win-win situation, and to realize Northeast Asian economic integration; Second, the three countries need further efforts to promotes the direct investment according to the needs of reality, especially to solve the concrete problems such as the investment obstacle that investors put forward, etc.; Third, for improving business environment and promoting investment, the governments of three countries need to set up the consulting mechanism, follow the implementation of every measure of improvement business environment, and study more measures; Fourth, it discussed that the legal frame about investment of the three countries should be set up. Three countries implemented actively the project measures and put forward in "The Final Report of the Research Group of East Asia”, and these measures formed the basic content of cooperation in specific fields between $10+3$. In addition, the three countries also emphasized that it was necessary to strengthen the coordination under $10+3$ cooperative frames. At the tripartite committee meeting held in June of 2004, the three sides emphasized above-mentioned common understandings again. At the same time, in order to strengthen the cooperation of regions of East Asia, the three countries improved and developed the relation with ASEAN further. China and ASEAN published "The Joint Declaration of the Strategic Partnership", planning the blueprint for the peace and prosperous partnership of both sides. Japan held Japan-ASEAN commemorate summit in December of 2003, published "The Declaration of Tokyo", and pointed out the direction for both relation development in the new century. Both sides still signed "The Action Plan of Japan-ASEAN", which included 120 concrete cooperative measures, such as the development in Mekong River region, the development of manpower resources, overall economic partnership and solving the transnational problem, etc.. In order to commemorate for the $15^{\text {th }}$ anniversary of establishment talk relation, in November of 2004 S. Korea and ASEAN published "The Joint Declaration of Overall Partnership Relation”, and began the negotiation to build the free trade district at the 
beginning of 2005. On November 27, 2004, the tripartite committees of China, Japan and S. Korea passed the cooperative action strategy of three countries, reaffirming five basic views about the tripartite cooperation which the leaders of three countries agreed unanimously in "Joint Declaration"; realizing that it is significant to make use of the complementary advantage of the tripartite economy; emphasizing that it is necessary to strengthen the further research, planning, coordinate and supervise of tripartite cooperation; believing that the establishment of closer overall partnership of the three countries would contribute for the peace, stability and development of the area and world and contribute to the efforts to set up community of east Asia too.

\section{Chinese Economic Increase Made the Pattern of Northeast Asian Cooperation in} Economy and Trade Changed

Table 1 Chinese import-export volume in 2001-2004 (Asia, S. Korea, Japan) Unit: ten thousand dollars

\begin{tabular}{|c|c|c|c|c|}
\hline & 2001 & 2002 & 2003 & 2004 \\
\hline Asia & 28813909 & 36062463 & 49553960 & 66502734 \\
\hline S. Korea & 3590990 & 4407117 & 6323106 & 9006821 \\
\hline Proportion in Asia (\%) & 12.46 & 12.22 & 12.76 & 13.54 \\
\hline Japan & 8775448 & 10190539 & 13357340 & 16788636 \\
\hline Proportion in Asia (\%) & 30.46 & 28.26 & 26.96 & 25.25 \\
\hline $\begin{array}{c}\text { Proportion of two } \\
\text { countries in Asia (\%) }\end{array}$ & 42.92 & 40.48 & 39.72 & 38.89 \\
\hline
\end{tabular}
China.

Data source: The customs of the People’s Republic of China counts, Department of Commerce of the People’s Republic of

In Northeast Asian regional economy trade, the trade volume of China to Japan and S. Korea accounted for $38.89 \%$ of the trade volume of China to the whole Asian (2004 data) (Table 1), and accounted for 22.3\% of the total foreign trade volume of China, and it was an important component of Chinese foreign trade. From 2001 to 2004, the trade volume between Japan and China nearly doubled, and the trade volume between S. Korea and China increased by 1.5 times (Table 1). At the same time, because the trade volume of China to European Union and ASEAN increased violently, the proportion of the trade volume of China to Japan and S. Korea volume accounting for Chinese total trade fell year by year (Table 1).

In the trade with China, S. Korea and Japan have become the largest adverse balance country of Chinese foreign trade. In 2004, the favorable trade balance of S. Korea to China was up to 51.23 billion dollars, and that of Japan to China was 20.86 billion dollars (Table 2), becoming two largest unfavorable balance countries of Chinese foreign trade. In the trade with China from 2002 to 2004, Japan and S. Korea have got the strength of the national economy of promotion, and spurred national economy to develop forward.

Table 2 Chinese adverse balance to Japan and S. Korea in 2002-2004

Unit: hundred million dollars

\begin{tabular}{|c|c|c|c|}
\hline Time & Country & Favorable balance volume & Rank in the world \\
\hline \multirow{2}{*}{2004} & S. Korea & 512.3 & 1 \\
\cline { 2 - 4 } & Japan & 208.6 & 1 \\
\hline \multirow{2}{*}{2003} & S. Korea & 230.4 & 2 \\
\cline { 2 - 4 } & Japan & 147.3 & 1 \\
\cline { 2 - 4 } & S. Korea & 130.8 & 3 \\
\hline
\end{tabular}

Data source: The customs of the People's Republic of China counts, Department of Commerce of the People's Republic of China. 
In the trade of China and S. Korea, S. Korea obtained the greatest interests from China's economic development. From 2002 to 2004, the trade volume of S. Korea and China was 197.37 billion dollars, and S. Korea obtained the favorable balance of 87.35 billion dollars from China, becoming the largest adverse balance country of China in three years.

Table 3 The top ten trading partner of China in 2004

Unit: hundred million dollars

\begin{tabular}{|c|c|c|c|c|c|}
\hline Rank & Country (Area) & 2004 & Same time rate (\%) & Rate (\%) & Rate change \\
\hline & The total value & 11547.7 & 35.7 & 100 & 0.0 \\
\hline 1 & European Union & 1772.9 & 33.6 & 15.4 & -0.2 \\
\hline 2 & U.S.A. & 1696.3 & 34.3 & 14.7 & -0.1 \\
\hline 3 & Japan & 1678.9 & 25.7 & 14.5 & -1.2 \\
\hline 4 & Hong Kong & 1126.8 & 28.9 & 9.8 & 0.5 \\
\hline 5 & ASEAN & 1058.8 & 35.3 & 9.2 & 0.0 \\
\hline 6 & S. Korea & 900.7 & 42.5 & 7.8 & 0.4 \\
\hline 7 & Taiwan & 783.2 & 34.2 & 6.8 & -0.1 \\
\hline 8 & Russia & 212.3 & 34.7 & 1.8 & -0.1 \\
\hline 9 & Australia & 203.9 & 50.3 & 1.8 & 0.2 \\
\hline 10 & Canada & 155.2 & 55.1 & 1.3 & 0.1 \\
\hline
\end{tabular}

Note: Arrange in an order from great to little according to the total import and export value of country or area.

Data source: The customs of the People's Republic of China counts, Department of Commerce of the People’s Republic of China.

In the economic trade of China and Japan, the trading partner status of China and Japan has changed. Comparing with the trade increase of China and other countries, the trade of China and Japan did not increase quickly. In the four years from 2000 to 2003, the average annual trade growth levels of China and principal trade partner were as follow: the trade with U.S.A. increased by $20.1 \%$, the trade with S. Korea increased by $27.0 \%$, the trade with ASEAN and European Union increased by 31.5\% and 22.2\% respectively, and the trade with Japan increased only by $19.6 \%$. In 2004, the trade growth levels of China and principal trade partner were as follow: the trade with U.S.A. increased by $34.3 \%$, the trade with S. Korean increased by $42.5 \%$, the trade with ASEAN and European Union increased by 33.6\% and 35.3\% respectively, and the trade with Japan increased only 25.7\% (Table 3), still in the minimum level. The proportion of the trade volume between China and Japan accounting for Chinese foreign trade presented the downward trend. Counted according to the Chinese customs, the proportion already dropped from about $20 \%$ in initial stage of the 1990 s to $15.7 \%$ in 2003 . The decline of the proportion also proved that the trade reliance on Japan of Chinese was subsiding. Since 1993 Japan has been the first major trade partner of China for 11 years in succession, and China was the second major trade partner of Japan. In 2004, the trade volume of China and European Union was 177.29 billion dollars, that of China and U.S.A. was 169.63 billion dollars, and that of China and Japan was 167.89 billion dollars (Table 3), so Japan has already turned to the third major trade partner of China. Meanwhile, the trade volume of China and Japan exceed the trade volume of U.S.A. and Japan, and China became the first major trade partner of Japan. It proves that the trade reliance on Japan of China reduced, and the trade reliance on China of Japan increased. This proves to reducing, and the trade to China of Japan relies on increasing. Japan economy went on shrinking in the fourth quarter of 2004, the fourth decline since the past 10 years. The future of Japan's economic recovery more and more depended on "health status" of the cooperation with China in economy and trade. Therefore, once Chinese economy fluctuates or the economic trade between China and Japan encounters difficulties, Japanese economy will suffer greater blow. 
In investment to China, greater changes have taken place in the investment to China of S. Korea and Japan. Since 2000, the execution amount of the direct investment to China of Japanese enterprises has increased by $16.6 \%$ every year, and that of S. Korea enterprises has increased $40.4 \%$ every year, which was higher than the growth level of Japan. By the first season of 2004, the contract value of the investment in China of S. Korean enterprises was up to 20 billion dollars, already exceeded Japan and became the first major country direct invest in China. Meanwhile, in view of Chinese economic growth, the amount of the yen loan (ODA) to China of Japan reduced year by year, and the way also changed. The Japanese loan to China carried on the package ways for five years cooperated with the five-year-plan of China in the past, since 1996 it changed to the way of 3 years add 2 years, in 2000 it changed into the way for one year. The amount of Japanese yen of loan was also less and less, reducing from 200 billion yen average annual in the end of the 1990s to less than 100 billion yen in 2003, and the project helped build changed to environmental protection, etc. from past economic infrastructure. Though the trade volume of Japan and China was increasing constantly, the growth rate was lower than that of S. Korea by $16.8 \%$.

\section{Competition and Difference that Chinese Economic Increase Brought to Northeast} Asia

Because of the long-term sustained and rapid development of Chinese economy, the Japanese status as the first economic giant of Asia was impacted, and it aggravated Japanese to worry about Chinese economic development. Japan and China launched the strong competition to lead Asian economy. They adopted own attitude each other in regional cooperation, and they each had own plans on the priority order and leading status to build up the community of East Asia, Northeast Asian free trade area, Southeast Asia free trade area, ASEAN-China free trade area, ASEAN-Japan free trade area, ASEAN-S. Korea free trade area, which made the integration process of the regional economics of East Asia develop slowly. Compared with Europe, the enormous difference in such respects as the economy, politics, religion, etc. between various countries of East Asia is another serious obstacle of setting up the regional community. The realistic method of China was from the easier to the more advanced, first to build up China-ASEAN free trade area, at the same time advance the signing of the free trade agreement of Northeast Asia, finally build up a community of East Asia and integrate progressively East Asia. S. Korea paid more attention to the construction of the Northeast Asian free trade area, hoping to set up the Northeast Asian free trade area first among three countries of China, Japan and S. Korea with the complementary economy, cultural homogeneity, and then absorb ASEAN to participate in, and finally build up an economic community. It wanted to take advantage of Chinese strength to improve its status and influence power in the negotiation of free trade area of Japan and S. Korea. The attitude of Japan was delicate particularly, Japan was afraid that S. Korea united China to restrict Japan, did not take its stand to the S. Korean proposition of "East Asia Summit Meeting”, and only emphasized that " $10+3$ " mechanism should continue keeping open. It was also unwilling to open its agriculture and farm products market to East Asian countries specializing in planting the rice equally. The thinking of Japan inclined to set up the community of East Asia with ASEAN first, and then absorb China and S. Korea to join, in the hope of establishing its leading position in the community of East Asia. The "Declaration of Tokyo" was the embodiment of this thinking. That Japan joined "The Southeast Asian Treaty of Friendship and Cooperation" showed that Japan would upgrade the connection with ASEAN in politics, economy, security and culture, in order to guarantee its position and influence on Southeast Asia. In the following 20 years, though China 
will improve the economic status in Southeast Asia greatly, Japan will still be the main partner of Southeast Asia on trade and investment. One European Union without the close cooperation between Germany and France is fragile, and equally one "Community of East Asia" without the good cooperation between China and Japan are unlikely to be realized too.

The impact on Japanese economy of Chinese economic development not only displays on the trade number of both sides, the more main one is that the power of China makes Japan have to orient own economic development strategy again. Under the motivation of China, Japan began to adjust its economic policy. Japan paid attention to "multilateral doctrine" under WTO traditionally, and held a cautious attitude towards signing the regional trade agreement. Nowadays, facing the reality that the regional trade accounts for half of the world trade, signing the regional economic cooperation agreement becomes the trend of the world commerce policy and "rule of the game", Japan began to change its traditional policy, reach the frame agreement of the bilateral trade with Singapore, is negotiating with S. Korea, Thailand Philippine, Malaysia. Japanese Kyodo News Service thought that Japan accelerated expanding the route of the free trade camp in Asia is to confront with China walked in ahead.

\section{Conclusion}

Chinese economic increase makes China become important strength to promote the process of regional cooperation; Chinese economic increase makes the pattern of Northeast Asian cooperation in economy and trade change; Competition and difference that Chinese economic increase brought to Northeast Asia. The key whether the cooperation of East Asia could be developed in a healthy way lies in the cooperation between China and Japan, so China and Japan must strengthen the coordination in the cooperative frame in East Asia. As the two biggest economy bodies and the most powerful country of East Asia, China and Japan have their own strong points each, and the advantages that each has are unable to be substituted within a long time. The integration process of East Asia can't go on smoothly without either China or Japan. The best way to break out the relations of China and Japan is the community of East Asia, under the common idea, share interests and keeping norm altogether, the mode of winning together that compete as well as cooperates is the rational choice of China and Japan in the integration process of East Asia.

\section{References:}

[1] CHEN Yu. Chinese Enterprises Have an Optimistic View of the Market of ASEAN. [2004-12-30]. http://www.bbwfish.com.

[2] Budy Damty. The Economic Relation Prospect between China and Indonesian Facing the ASEAN-China Free Trade Area. [2004-12-24]. http://news.sina.com.

[3] FU Ying. Asian Situation and Periphery Diplomacy: Chinese Rise is Asian Important Change. The Report of Current Events, 2003-11-21.

[4] HE Hong-ze, ZOU De-hao. The New York Times Published the Long Article to Report China's Economic Fast Development. [2004-12-08]. http://www.sina.com.cn.

[5]YANG Kai. The Community of East Asia: The Difference under Prosper. Beijing Youth Daily. [2004-12-24]. http://www.sina.com.cn.

(Edited by Jimmy Wang, Gavin Dai and Shirley Hu) 